\title{
TECHNICAL EFFICIENCY LEVEL OF ISLAMIC BANK IN INDONESIA
}

\author{
Alfu Laila Fiafifah ${ }^{1}$, Darwanto ${ }^{2 *}$ \\ ${ }^{1,2}$ Department of Economics and Development Studies, Faculty of Economics and \\ Business, Universitas Diponegoro \\ Jalan Prof. Soedarto SH, Tembalang, Semarang, Indonesia \\ alfulaila685@yahoo.com \\ darwanto@live.undip.ac.id
}

\begin{abstract}
One of the common measurements used to evaluate a company's performance is the efficiency performance which indicates a company's efficiency score in utilizing inputs to produce outputs. This study aims to evaluate the performance of state-owned Indonesian Islamic banks by measuring their technical efficiency along with the determinant factors of their efficiency over the period 2014-2017. In this study, DEA, a non-parametric technique method, is employed to measure the efficiency of four state-owned Indonesia Islamic banks. Another method, Tobit-regression, is used to identify the determinant factors of their efficiency. Four state-owned Indonesian Islamic banks are chosen as the object of this study, namely Bank Syariah Mandiri, BNI Syariah, Bank Rakyat Indonesia Syariah, and $B T N$ Syariah. The results of calculation using DEA methos show that the average efficiency level of all state-owned Indonesian Islamic banks over four consecutive yerars is 100\%. It means that all the state-owned Indonesian Islamic banks operating in Indonesia have been able to optimize all their resources and are considered efficient over the period 2014-2017. Tobit-regression model results show that bank size, capitalization, and profitability significantly affect all state-owned Islamic banks' efficiency, while bank expenses do not have a significant effect on their efficiency.
\end{abstract}

Keywords: Efficiency; Islamic Bank; DEA; Tobit 


\begin{abstract}
Abstrak
Salah satu pengukuran yang umumnya digunakan untuk evalusi kinerja perusahaan adalah kinerja efisiensi yang menunjukan skor efisiensi perusahaan dalam menggunakan input untuk menghasilkan output. Penelitian ini bertujuan untuk mengevaluasi kinerja Bank Umum Syariah dibawah BUMN dengan mengukur efisiensi teknis bersamaan dengan factor-faktor yang berpengaruh terhadap tingkat efisinesi selama periode tahun 2014-2017. Penelitian ini menggunakan metode non-parametrik, DEA yang digunakan untuk mengukur tingkat efisiensi empat Bank Umum Syariah di bawah BUMN. Penelitian menggunakan metode regresi Tobit untuk mengidentifikasi factor-faktor yang berpengaruh terhadap tingkat efisiensi bank tersebut. Empat Bank Umum Syariah dibawah BUMN yang dipilih sebagai objek penelitian meliputi Bank Syariah Mandiri, BNI Syariah, Bank Rakyat Syariah Indonesia dan BTN Syariah. Hasil penelitian berdasarkan metode DEA menunjukan bahwa tingkat efisiensi rata-rata semua Bank Umum Syariah dibawah BUMN selama empat tahun berturut-turut adalah 100 persen. Hal tersebut menunjukan bahwa semua Bank Umum Syariah dibawah BUMN yang beroperasi di Indonesia telah mampu mengoptimalkan semua sumber daya dan dianggap efisien selama periode tahun 201-2017. Hasil model regresi Tobit menunjukan bahwa variable ukuran bank, kapitalisasi dan profitabitas secara signifikan mempengaruhi efisiensi semua Bank Umum Syariah dibawah BUMN, sedangkan biaya bank tidak memiliki pengaruh yang signifikan terhadap efisiensi bank tersebut.
\end{abstract}

Kata kunci: Efisiensi; Bank Syariah; DEA; Tobit 


\section{INTRODUCTION}

The existence of Islamic banks aims to promote, develop, and apply the principles of Islamic economics to various related financial transactions. The Islamic banking market share is still relatively small compared to that of conventional banking. Challenges that must be addressed include the lack of public knowledge about the importance role of Islamic banking, limited capital, human capital issues, competitive and innovative sharia products that meet the community needs, infrastructure business models and procedures, provision of effective and efficient distribution channels, and government support. The current growth of national Islamic banking is indeed still far from expectations. According to data from the Financial Services Authority (2017), to date the total assets of Islamic banking have only reached $5.18 \%$ of the total assets of the overall banking sector nationwide.

Table 1. The Growth of Islamic Banks and Conventional Banks Number Year 2013 - 2017

\begin{tabular}{lccccc}
\hline \multicolumn{1}{c}{ Group of Banks } & $\mathbf{2 0 1 3}$ & $\mathbf{2 0 1 4}$ & $\mathbf{2 0 1 5}$ & $\mathbf{2 0 1 6}$ & $\mathbf{2 0 1 7}$ \\
\hline Islamic Banks & 11 & 12 & 12 & 13 & 13 \\
Conventional Banks & 120 & 119 & 118 & 116 & 115 \\
Islamic Business Units & 23 & 22 & 22 & 21 & 21 \\
Islamic Rural Banks & 163 & 163 & 163 & 166 & 167 \\
\hline
\end{tabular}

Source: Indonesia Banking Statistics 2013-2017, processed

Table 1. shows the growth of Islamic and conventional banks in Indonesia consisting of sharia banks, conventional banks, sharia business units and sharia rural banks from 2013 to 2017. As time goes by, the growth of Islamic commercial banks (BUS) in Indonesia shows an increase. Since 2013 Islamic banks in Indonesia have begun to increase even though the increase is not significant but this indicates that Islamic banks experienced growth until 2017. While conventional banks show a trend that tends to decline every year until 2017. While Islamic business units (UUS) and Islamic rural banks (BPRS) experience slight fluctuations but tend to be stable from 2013 to 2017.

Djaelani (2017) in the Seminar on Islamic Economic Society (MES) explained that the current state of Islamic banking is fluctuated due to the lack of Islamic banking economies of scale (Masyrafina, 2017). Since 2016 the business competition in the financial industry has been increasing due to the existing 
ASEAN economic community (MEA) agreements, including the banking industry in accordance with the ASEAN Banking Integration Framework (ABIF) agreement. Islamic banking in Indonesia will have a vast growth opportunity if the performance capacity and competitiveness of the banking sector are to be improved so that Islamic banks are able to operate efficiently. One way to improve the performance capacity of Islamic banks is by increasing the efficiency of Islamic banks (Idhat, 2015).

Berger and Mester (in Fathony, 2012) stated that banking efficiency in general can be viewed from two perspectives, namely micro and macro perspectives. Micro perspective explains that banks are able to operate and develop efficiently in high banking competition. If a bank is unable to compete, the bank must exit the market, either because of competitive prices, bank products quality or service level. Macro perspective suggests that an efficient banking industry can influence the cost of intermediation and the stability of the financial system as a whole. This is due to the very strategic role of banks as intermediary institutions and financial service producers.

Banking efficiency measurement is needed to determine the ability of banks to optimize all available resources and benefits provided by banks to the public as customers (both as depositors and financing customers) (Firdaus \& Hosen, 2014). The level of efficiency achieved is different for each bank including Islamic Banking. Not all banks achieve a 100 percent efficiency level, which means the bank still does not optimize all of its resources (Amirillah, 2014; Harjum Muharam $\&$ Pusvitasari, 2007). The level of efficiency of a bank can be higher or lower than other banks in the banking sector (Ǩepková, 2014). Rogowski (in Siudek, 2008) explained that the measurement of banking efficiency is done using analysis of technical efficiency and scale efficiency.

Technical efficiency is the maximization of output results from the production process of a number of inputs. While scale efficiency is the achievement of constant return to scale with different bank efficiency range for each allocation. The allocation efficiency is said to be achieved if a bank can determine the output that can maximize profits. The level of bank efficiency is influenced by several factors 
such as profitability, bank size, capitalization, financing risk and others (Hartomo, Deny Dwi, 2018; Ismail, Shabri Abd. Majid, \& Rahim, 2013; Nguyen, 2018).

The level of efficiency of State-Owned Enterprises Islamic Commercial Banks (BUMN BUS) can be a benchmark for the success of a country's economic development. It is expected that State-Owned Islamic Commercial Banks (SOE ICB) will become a pillar of national economic growth. The results of the literature study show that several studies regarding the previous Islamic Commercial Banks (BUS) focused more on Islamic banks or UUS in general. In addition, the latest BUS efficiency data in 2014-2017 has not been found, particularly SOE ICB technical efficiency data. The existence of several problems that have been explained, makes the author interested in conducting a study similar to the case that focuses on SOE ICB. Therefore, in this research the author aims to evaluate the performance of state-owned Indonesian Islamic bank by measuring their technical efficiency along with the determinant factors of their efficiency over the period 2014-2017.

\section{RESEARCH METHODS}

It is necessary to improve the performance of Islamic banking in order to achieve the existing targets. One of the alternatives to improve the performance is by increasing efficiency, since it is a performance measurement that is quite popular in financial institutions in this case is Islamic banking. Measurement of efficiency can include technical efficiency, allocation/price and economic efficiency. This study measures and analyzes technical efficiency using the Data Envelopment Analysis (DEA) analytical method.

Furthermore, tobit-regression analysis are used to identify factors influencing the level of efficiency and the relationship among variables to the level of efficiency and the relationship among variables to the level of efficiency of each bank. This research is limited by several things. First, the time period of data to identify the level of efficiency of state-owned Islamic banks used in this study were in the period of 2014-2017. Second, the Islamic banks analyzed are Islamic state-owned enterprises which are the driving force of economy as goods exemplars for non- 
state-owned Islamic banks. It is also expected that state-owned Islamic banks can be the leader of national economic growth.

The population used in this study includes all state-owned Islamic banks and recorded in BI for the period of 2014-2017. Sample is a small part of the population that will be the object of a research. The sample from this study is taken using a purposive sampling method of wh which the sample is not taken randomly but certain considerations to obtain the data more representative.

Sample determination criteria are: 1) Islamic Commercial Banks which are SOEs and registered at Bank Indonesia in the observation period of 2014-2017; 2) Islamic Commercial Banks listed in Bank Indonesia whose financial reports have been published from 2014-2017; and 3) Islamic Commercial Banks listed in Bank Indonesia which are still operating in the period of 2014-2017. Based on the criteria for sampling determination, the number of samples to be used in this study are as follows: 1) Bank Syariah Mandiri; 2) BNI Syariah; 3) BTN Syariah; and 4) BRI Syariah.

This study uses secondaray data sourced from Islamic Bank financial statements in the form of annual financial reports published in 2014-2017 period. The secondary data is collected by the documentation method. The documentation method includes gathering information and data collected through literature studies or exploration of literature like financial reports. The secondary data needed in this study include: 1) the amount of deposits or amount of wadi'ah owned by the bank in the financial statements of the bank concerned during the 2014-2017 observation period; 2) the amount of bank assets obtained from the financial statements of Islamic banks during the 2014-2017 observation period; 3) other operating expenses are derived from labor costs and banking activities such as general and administrative expenses, personnel expenses, allowance for possible losses on earning assets and wadi'ah deposit bonus expenses during the 2014-2017 observation period; 4) the amount of financing obtained from those particular Islamic bank financial statements during the 2014-2017 observation period; and 5) operating income obtained from the income statement contained in the financial statements of Islamic banks during the 2014-2017 observation period. 
The DEA method use the input and output variables to calculate efficiency. The analysis to calculate banking efficiency is conducted by measuring the ratio between the inputs used by the Islamic banks in this study with the output produced. Analyzing efficiency can measure the unit performance of an organization such as banking (Ardiani, 2019). DEA applies descriptive and quantitative analysis. Descriptive analysis focuses on exploration of phenomena or describing the studied variables. While quantitative analysis focuses on aspects that are measured objectively in the form of social phenomena into certain variables or indicators. The analytical tool in this study is Data Envelopment Analysis (DEA) using an output oriented intermediation approach. The software used for data tabulation is Microsoft Excel 2010 and then to calculate the value of efficiency using the Banxia Frontier Analysis program.

Basically, DEA determines the weight for each particular input and output in each unit of economic activity. The weight is general in nature and not in negative value or it can be said that each economic activity unit in the sample uses a number of equal weights to obtain the ratio and the ratio may not exceed one (total weighted output / total weighted input $\leq 1$ ). But in reality there are more than one input and output exist (Ramanathan, 2003 in Mustainah, Saifi, \& NP, 2017).

$$
\text { Eficiency }=\frac{\text { total weighted output }}{\text { total weighted input }}
$$

The model used in this study is the VRS model popularized by Banker, Charnes and Cooper in 1978. This model is the result of the development of the first model; the BCC model popularized by Banker, Charnes and Cooper in 1984. The CCR assumption applies if the unit economic activities run optimally while the BCC model applies if the economic activity unit is not optimal or has production constraints such as competition, government regulations and financial constraints (Tanjung \& Devi, 2013). Variable Return to Scale (VRS) is the assumption of the BCC model which results in technical efficiency and scale but they are separated. Therefore this model is often called a pure engineering efficiency model. 
In general, each unit of economic activity has similar characteristics. Usually each bank has a diverse production level benchmark. This means that each bank has its own role in determining its level of efficiency. This CCR model reflects the results of both technical efficiency and scale, while the BCC model only reflects technical efficiency. So it can be concluded that scale efficiency is the ratio resulting from the comparison of efficiency on the CCR model and the BCC model.

$$
S E=\frac{T E C R S}{T E V R S}
$$

If the result of the $\mathrm{SE}$ value =1, it can be interpreted that the economic activity unit operates optimally or shows the best scale efficiency. If the result of the value of $\mathrm{SE} \leq 1$, it means that economic activity unit is inefficient Coelli et.al, 1998 (in Pohan, 2015).

The variable used in DEA includes input variable and ouput variables. The input variables are : 1) deposits, funds collected by Islamic banks from the community, both individuals and legal entities in units of millions of rupiah (the total deposits are classified into several types, namely sharia demand deposits, sharia deposits, and sharia savings); 2) total assets, the total assets or assets owned by Islamic banks can be in the form of securities or fixed assets (total assets include ijara, mudaraba, murabaha, salam, itisna, and reserves; and 3) other operating expenses, the basic costs incurred by Islamic banks for their employees, including labor costs, general administration, personnel costs, bonus costs for wadi'ah and others. The output variables are : 1) financing, one of the products of Islamic banks, namely in the form of channeling funds to general public, both individuals and legal entities in accordance with Islamic principles, namely muamalah (man to man contract). These financing products can be divided into several types, namely tijaroh, ijarah, syirkah, hiwalah, rahn, qardh, wakalah, kafalah, and others; and 2) operational income, income derived from the results of economic activities carried out by Islamic banks. Operating income becomes one of the variables because income is the revenue for Islamic banks from the results of the bank's operational activities. It covers income earned from fund disbursement activities, in the form of 
buying and selling revenue including mudaraba, salam, and istisna, leasing or ijarah, and revenue from profit sharing including mudaraba and musyaraka.

Tobit-regression analysis are used to identify factors influencing the level of efficiency and the relationship among variables to the level of efficiency of each bank. The tobit model aims at getting the best results from each coefficient. The analytical tool used in the tobit-regression is Eviews 9 software. This study uses Tobit regression model because the data in this study are censured data types, meaning the value of the dependent variable is limited and can only range $0-100$. Although Tobit analysis is part of the regression analysis, in application it does not require a test of normality, heteroscedasticity, multicollinearity, and autocorrelation which is usually also called an assumption. The test used in Tobit regression analysis is Likelihood Ratio and Wald test to find out whether or not the estimation parameters are feasible. This likelihood ratio and Wald test is often used in Tobit regression model by Robinson, Bera and Jarque 1985 (in Nurkholis \& Purwanto, 2015). Systematically the Tobit in this study can be written as follows:

$$
\mathrm{Y}=\beta 0+\beta 1 \mathrm{X} 1+\beta 2 \mathrm{X} 2+\beta 3 \mathrm{X} 3+\beta 4 \mathrm{X} 4+\varepsilon
$$

Where:

$\begin{array}{ll}\mathrm{Y} & \text { : efficiency; } \\ \beta 0 & \text { : intercept; } \\ \mathrm{X} 1 & \text { : bank size; } \\ \mathrm{X} 2 & \text { : profitability; } \\ \mathrm{X} 3 & \text { : capitalization; } \\ \mathrm{X} 4 & \text { : bank expenses; } \\ \beta 1, \beta 2, \beta 3, \beta 4 & \text { : regression coefficients; } \\ \varepsilon & \text { : error standard. }\end{array}$

The dependent variables in this search is efficiency in banking, particularly technical efficiency, which can be interpreted as the ability of a bank to obtain maximum output from particular input utilization. The independent variables are bank size, profitability, capitalization, and bank expenses. Bank size is obtained from the total assets owned. The size of the company in the form of company assets that also describes the health of a bank. Laroche, Babin, Lee, Kim, \& Griffin (2005) 
and Ahmad \& Mohamad Noor (2011), explained that bank size has a positive and significant relationship to efficiency. Mokhtar et al (2008) found that there is a positive relationship between bank size and technical and cost efficiency. A company size is proxied using $n$-logged total assets.

Profitability (ROA) is measurement that illustrates a bank's performance to earn income. The profitability ratio also shows how much the bank can get income with a number of assets owned. Profitability in Islamic banks is obtained from the ratio between net income in the form of mudharabah, murabahah, musyarakah, etc. with the total assets of Islamic banks. Zamil, Nor Aiza Mohd. (2006) in his research stated that the level of profitability will positively influence the level of efficiency. Capitalization is a pivotal component in banking; it is the main power or strength a bank must own. It includes capital adequacy, capital composition, capital access, and the ability of capital to cover troubled assets. Capital here includes paid up capital, additional paid-in capital, other reserves, and comprehensive income. The capitalization rate shows how the capital owned by a bank is proportional to the number of assets owned by the bank. The lower the level of capitalization, the higher the risk the bank will bear (Sufian, Kamarudin, \& Noor, 2012) resulting in bank inefficiency.

Research related to the relationship between capital and efficiency by Ahmad \& Mohamad Noor (2011) shows a significant positive effect. Bank expenses are the costs that must be incurred by the bank to carry out its economic activities. Mohamad Noor and Ahmad (2011) mentioned that there is a positive influence between bank expense and efficiency level. Bank expense here includes wadiah bonus fees, commission expenses, salary expenses, labor expenses, promotions, etc.

The hypothesis in this study are: 1) H1: bank size has a positive effect on the level of efficiency of Islamic banks; 2) H2: profitability has a positive effect on the level of efficiency of Islamic banks; 3) H3: capitalization has a positive effect on the efficiency of Islamic banks; and 4) H4: bank expenses have a negative effect on the level of efficiency of Islamic banks. 


\section{RESULTS AND DISCUSSION}

\section{Descriptive Analysis of Bank Size, Profitability, Capitalization, and Bank Expenses Variables}

The descriptive analysis of the independent variable (bank size, profitability, capitalization, and bank expenses) aims to look at the characteristics of data seen from the mean or average, the standard deviation, the maximum value and the minimum value of each of the representative ratios calculation. Bank size variable has a minimum value of 16.50832 and a maximum value of 18.29216. The average value is 17.30668 with a standard deviation of 0.558330 , which can be interpreted as a variation in the bank size. This shows that banks are effective in utilizing bank size variables to create maximum profits. Profitability variable produces a minimum value of -0.969724 and a maximum value of 0.022346 . The average value is -0.023751 and the standard deviation is 0.172694 meaning that there is still a variation between the ratio of net income and the level of profitability. It can be concluded that Islamic banks are lack of probability which causes small amount of income.

Capitalization variable produces a minimum value of -0.078938 and a maximum value of 1.112912. The mean is 0.323504 and the standard deviation is 0.417291. This means that Islamic banks are effective in utilizing their capital to increase maximum profits. Bank expenses variable produces a minimum value of 0.015039 and a maximum value of 0.101504 . The mean value is 0.052429 and the standard deviation is 0.025206 . The results show that bank expenses in Islamic banks are effectively controlled but can still be improved.

\section{Efficiency Analysis}

The results of technical efficiency of Bank BNI Syariah, BRI Syariah, BTN Syariah and Bank Syariah Mandiri is displayed in this discussion. The data of input and output variables used are obtained through financial statements published by Sharia banks that are used as objects of observation. As already explained, the DEA displays the results of efficiency in the form of scores within a range of 1-100 
(Abidin \& Endri, 2009). A value of 100 indicates that the bank is able to maximize all of its resources.

Whereas if the value is less than 100, it indicates that the bank is less efficient or has not been able to maximize its resources properly, and is considered not able to carry out its role as an intermediary institution to the fullest (Zamil, Nor Aiza Mohd., 2006). Measurements using this DEA method are presented in tables and graphs that illustrate the level of achievement of efficiency of each bank used as the object of the observation calculated every quarter from 2014 to 2017.

Table 2. Technical Efficiency of Indonesian Islamic Banks Quarter 1 - 4 Year 2014 - 2017. (Based on DEA Method Calculation)

\begin{tabular}{lcc}
\hline \multicolumn{1}{c}{ Banks } & Efficiency (\%) & Average (\%) \\
\hline BNI Syariah 2014 & 100 & \\
BNI Syariah 2015 & 100 & 100 \\
BNI Syariah 2016 & 100 & \\
BNI Syariah 2017 & 100 & \\
\hline BRI Syariah 2014 & 100 & 100 \\
BRI Syariah 2015 & 100 & \\
BRI Syariah 2016 & 100 & 100 \\
BRI Syariah 2017 & 100 & \\
\hline BTN Syariah 2014 & 100 & \\
BTN Syariah 2015 & 100 & \\
BTN Syariah 2016 & 100 & 100 \\
BTN Syariah 2017 & 100 & \\
\hline Bank Syariah Mandiri 2014 & 100 & \\
Bank Syariah Mandiri 2015 & 100 & \\
Bank Syariah Mandiri 2016 & 100 & \\
Bank Syariah Mandiri 2017 & 100 & \\
\hline
\end{tabular}

Source : processed data, 2019

This table shows the average efficiency score results of each bank. It appears that all banks have an average efficiency of 100\% during the 2014-2017 observation period. Based on the results, it can be concluded that state-owned Sharia banks in Indonesia are already efficient or maximum in utilizing their resources to produce optimal output. This shows that all banks gain trust from customers as banks that 
are efficient and useful for the distribution of their products to become the community's reliance in obtaining financing.

\section{Tobit Regression Test Results}

Analysis of the Tobit regression model uses the Banxia Frontier Analysis software program. The regression results of the bank size, capitalization, profitability and bank expenses influence based on the principles of the entity theory on the level of efficiency are as follows:

Efficiency $=117,377-1,041$ (bank size) $+9,222$ (profitability) $-0,511$ (capitalization) - 0,060 (bank expenses) +e (4)

The results of the study show the influence of bank size, capitalization, profitability and bank expenses based on the principles of the entity theory on the level of efficiency. The bank size variable has a probability value of 0.1656 , capitalization variable has a probability value of 0.6099 and the expense bank variable has a probability value of 0.8044 , while the profitability variable has a value of 0.7800 . So, these three variables have no effect because the resulted probability value is $<0.05$. To find out their scale and influence can be seen from the $\mathrm{z}$-statistic value. The bank size variable has a negative effect of -1.041 , the capitalization variable has a negative effect of -0.511 while the bank expense variable has a positive influence also at -0.060 , while the profitability variable has a positive effect of 9.222 .

The result of F- statistics-simultant test (F-test) explains that explains the simultaneous effect independent variables on the dependent variables. The calculated $F$ value is 96.312 and the probability is 0.0000 where $0.000<0.05$. It can be concluded that the independent variables, namely bank size, capitalization, profitability and bank expenses have a significant positive effect on the dependent variables, namely the efficiency of Islamic banks. While, the result of likelihood ratio test shows probability of the model is 0.40 . It meas that the independent 
variables (bank size, capitalization, profitability, and bank expenses) concurrently influence the dependent variables (technical efficiency).

\section{The Influence of Bank Size On Islamic Banks Efficiency}

The partial test results of bank size variable on the efficiency of the Islamic banks being observed show a probability value of 0.1656 and the coefficient value shows a negative of -1.0417. These results indicate that bank size has no effect on efficiency because the value of probability is $<0.05$. Then the hypothesis which states the size of a bank has a positive effect on the efficiency of Islamic banks is rejected. In this case bank size is a reflection of the aspects owned by an Islamic bank and it shows the characteristics of that Islamic bank.

This result is in line with the research conducted by Fachrudin (2011) who found that company size do not affect company performance. This shows that the size of the company does not guarantee that the company will have a good performance. Huang \& Song (2002) and Talebnia, Valipour, \& Shafiee (2010) also found that there is no effect of company size on company performance.

\section{The Influence of Capitalization on Islamic Banks Efficiency}

The partial test results of capitalization variable on the efficiency of the Islamic banks being observed show a probability value of 0.6099 with a coefficient value of -0.5110 on negative direction. This result shows that capitalization has no effect on technical efficiency because the value of probability is $<0.05$. Then the second hypothesis which states capitalization has a positive effect on the efficiency of Islamic banks is rejected.

This result is in line with Permana \& Adityawarman's research (2015) stated that capitalization do not affect company performance. This capitalization is obtained from the ratio of total equity to total assets. It can be concluded that the amount of capital owned by banks does not guarantee its efficiency level. Wahid's research (2016) found out that level of capitalization, asset quality, inflation and post crisis dummy has negative effect on the efficiency Islamic and conventional banks in Malaysia. 


\section{The Influence of Profitability on Islamic Banks Efficiency}

The partial test results of profitability variable on the efficiency of the Islamic banks being observed show a probability value of 0.7800 with a coefficient value of positive results of 9.2224. This result indicates that profitability does not affect the efficiency of Islamic banks because the value of probability is $<0.05$. This shows that the profitability variable has a significant effect on efficiency so the hypothesis which states profitability has a positive effect on the efficiency of Islamic banks is rejected.

According to Kasmir (2012) profitability ratio is ratio to measure a company's ability to seek profits. This ratio also gives a measure of management effectiveness of a company. Profitability does not affect efficiency because premiums and investments are not reused for company operations so that they do not directly affect efficiency.

\section{The Influence of Bank Expenses on Islamic Banks Efficiency}

The partial test results of bank expenses variable on the efficiency of the Islamic banks being observed show a probability value of 0.8044 with a coefficient of 0.0606 on negative direction. These results indicate that bank expenses variable has no effect on efficiency because the value of probability is $<0.05$. So the hypothesis that bank expenses has a negative influence on the efficiency level of Islamic banks is accepted.

Bank expenses are the result of a comparison between operating expenses and total assets. Included in operating expenses are general administrative expenses, interest expenses, labor costs, marketing costs and so forth. This bank expenses ratio describes the costs incurred by banks compared to assets owned by banks. Banks with high ratios make the bank less efficient. The result of this study is in line with the research conducted by Benarda, Sumarwan, \& Hosen (2016) stated that bank expenses do not affect the performance of Islamic banks. The same results were also found by Sambasivam \& Ayele (2013) bank expenses do not affect company performance. 
The result of this study shows that not all the Islamic banks being observed show maximum efficiency. Some are inefficient due to financing and operating income variables. While the results of the analysis using Tobit model show that the bank size, profitability, capitalization, and bank expenses variable have no effect on Pure Technical Efficiency (PTE).

\section{CONCLUSION}

Based on the data and results of the analysis that have been conducted, it can be concluded that all SEO Islamic banks in the 2014-2017 period have relatively perfect efficiency values. In other words, all state-owned Islamic banks have worked efficiently for four consecutive years (2014-2017) since they are able to produce maximum output with a limited number of inputs. Bank size, capitalization, profitability and bank expenses have a positive and significant influence concurrently on the dependent variable, namely the efficiency of the Islamic banks in as proved by the Wald and the likelihood ratio tests.

By measuring technical efficiency of Islamic Commercial Banks, the results of this study are expected to provide information used for evaluation for the management of each Islamic Commercial Bank regarding the performance achieved, especially in achieving optimal efficiency levels during the period of this study. Financial service industry players, especially Islamic banks, can increase bank size, capitalization, profitability, and reduce bank expenses. One of the ways is to increase financing or create new products that conventional banks do not have. Things that need to be considered by the management of each Islamic Commercial Bank are the factors that influence efficiency as stated in this study, namely bank size, capitalization, bank expense and profitability.

Suggestions for future researchers who want to continue the research can further deepen the discussion about the efficiency of Islamic banks since the efficiency vary. In addition, other variables can be added which theoretically affect efficiency. In further research, it is expected to develop methods of efficiency measurement with other Frontier methods. This is because the efficiency measurement method will continue to develop. So various developments regarding 
measuring the level of efficiency are very possible things to explore regarding the efficiency of a bank.

\section{REFERENCES}

The Holy Quran and Hadith

Abidin, Z., \& Endri. (2009). Kinerja Efisiensi Teknis Bank Pembangunan Daerah : Pendekatan Data Envelopment Analysis ( DEA ). Jurnal Akuntansi Dan Keuangan, 11, 21-29. Retrieved from http://jurnalakuntansi.petra.ac.id/index.php/aku/article/view/17863

Ahmad, N. H., \& Mohamad Noor, M. A. (2011). The Determinants (of) Efficiency and Profitability of World Islamic Banks. International Conference on EBusiness, Management and Economics.

Amirillah, A. (2014). Efisiensi Perbankan Syariah Di Indonesia. JEJAK Journal of Economics and Policy. https://doi.org/10.15294/jejak.v7i1.3596

Ardiani, N. (2019). the Efficiency of Zakat Collection and Distribution: Evidence From Data Envelopment Analysis. Al-Uqud: Journal of Islamic Economics, 3(1), 54. https://doi.org/10.26740/al-uqud.v3n1.p54-69

Benarda, Sumarwan, U., \& Hosen, M. nadratuzzaman. (2016). Tingkat Efisiensi Industri Asuransi Jiwa Syariah Menggunakan Pendekatan Two Stage Data Envelopment Analysis. Jurnal Aplikasi Bisnis Dan Manajemen, 2(1), 64-72. https://doi.org/10.17358/JABM.2.1.64

Efferin, S. (2008). Metode Penelitian Akuntansi: Mengungkap Fenomena dengan pendekatan Kuantitatif dan Kualitatif. Yogyakarta: GRAHA ILMU.

Fachrudin, K. A. (2011). Analisis Pengaruh Struktur Modal, Ukuran Perusahaan, dan Agency Cost Terhadap Kinerja Perusahaan. Jurnal Akuntansi Dan Keuangan. https://doi.org/10.9744/jak.13.1.37-46

Fathony, M. (2012). Estimasi Dan Faktor-Faktor Yang Memengaruhi Efisiensi Bank Domestik Dan Asing Di Indonesia. Jurnal Keuangan Dan Perbankan.

Firdaus, M. faza, \& Hosen, M. N. (2014). Efisiensi Bank Umum Syariah Menggunakan Pendekatan Two-Stage Data Envelopment Analysis. Buletin Ekonomi Moneter Dan Perbankan. https://doi.org/10.21098/bemp.v16i2.31

Harjum Muharam, \& Pusvitasari, R. (2007). Analisis Perbandingan Efisiensi Bank Syariah di Indonesia Dengan Metode Data Envelopment Analysis (periode Tahun 2005). Fakultas Ekonomi Universitas Diponegoro Semarang.

Hartomo, Deny Dwi, W. D. E. (2018). Efisiensikah Bank Umum Syariah di Indonesia. Jurnal Bisnis \& Manajemen, 18(1), 53-67.

Huang, S. G. H., \& Song, F. M. (2002). The Determinants of Capital Structure: Evidence from China. SSRN Electronic Journal. 
https://doi.org/10.2139/ssrn.320088

Idhat, D. G. (2015). Ini 7 Masalah Bank Syariah. Retrieved October 23, 2018, from https://m.tempo.co/read/news/2015/11/22/087721104/ini7-masalah-banksyariah

Ismail, F., Shabri Abd. Majid, M., \& Rahim, R. A. (2013). Efficiency of Islamic and conventional banks in Malaysia. Journal of Financial Reporting and Accounting. https://doi.org/10.1108/JFRA-03-2013-0011

Kasmir. (2012). Analisis Laporan Keuangan. Jakarta: PT. Rajagrafindo Persada.

Laroche, M., Babin, B. J., Lee, Y. K., Kim, E. J., \& Griffin, M. (2005). Modeling consumer satisfaction and word-of-mouth: restaurant patronage in Korea. Journal of Services Marketing. https://doi.org/10.1108/08876040510596803

Masyrafina, I. (2017). Pangsa Pasar Perbankan Syariah Harus 15 Persen Agar Efisien. Retrieved October 23, 2018, from https://www.republika.co.id/berita/ekonomi/syariahekonomi/owxrlp368/tradisi-ramadhan

Mokhtar, H. S. A., Abdullah, N., \& Alhabshi, S. M. (2008). Efficiency and competition of Islamic banking in Malaysia. Humanomics. https://doi.org/10.1108/08288660810851450

Muhamad Azhari Wahid. (2016). Comparing the Efficiency of Islamic and Conventional Banks Based on the Evidence from Malaysia. Journal of Muamalat and Islamic Finance Research.

Mustainah, H., Saifi, M., \& NP, M. W. E. (2017). Analisis Perbandingan Tingkat Efisiensi Bank Umum Swasta Nasional dan Bank Asing di Indonesia Berdasarkan Data Envelopment Analysis. Jurnal Administrasi Bisnis, 44(1), 24-30.

Nguyen, T. L. A. (2018). Diversification and bank efficiency in six ASEAN countries. Global Finance Journal. https://doi.org/10.1016/j.gfj.2018.04.004

Nurkholis, \& Purwanto, A. (2015). Analisis Faktor-faktor yang Mempengaruhi Kebijakan Dividen (Studi Empiris Pada Perusahaan Manufaktur yang Terdaftar di BEI Periode 2010-2013). Diponegoro Journal of Accounting, 4(2), 211-220.

Otoritas Jasa Keuangan. (2017). Indonesia Banking Statistics. Retrieved from https://www.ojk.go.id/

Permana, F. Y., \& Adityawarman. (2015). Analisis Faktor-Faktor yang Mempengaruhi Tingkat Efisiensi Perankan Syariah di Indonesia. Diponegoro Journal of Accounting, 4, 1-14. Retrieved from http://ejournals1.undip.ac.id/index.php/accounting

Pohan, A. A. (2015). Efisiensi Kinerja Bank Umum Syariah dan Bank Pembiayaan Rakyat Syariah di Indonesia. Institut Pertanian Bogor.

Řepková, I. (2014). Efficiency of the Czech Banking Sector Employing the DEA 
Window Analysis Approach. Procedia Economics and Finance. https://doi.org/10.1016/S2212-5671(14)00383-9

Sambasivam, Y., \& Ayele, A. G. (2013). A Study On The Performance Of Insurance Companies In Ethiopia. International Journal of Marketing, Financial Services \& Management Research.

Siudek, T. (2008). Theoretical Foundations of Banks Efficiency and Empirical Evidence from Poland. Social Research, 3(13), 150-158.

Sufian, F., Kamarudin, F., \& Noor, N. H. H. M. (2012). Determinants of revenue efficiency in the Malaysian Islamic banking sector. Journal of King Abdulaziz University, Islamic Economics. https://doi.org/10.4197/Islec.25-2.7

Sugiyono. (2010). Metode Penelitian Pendidikan Pendekatan Kuantitatif, Kualitatif dan $R \& D$. Bandung: Alfabeta.

Talebnia, G., Valipour, H., \& Shafiee, S. (2010). Empirical Study of the Relationship between Ownership Structure and Firm Performance: Some Evidence of Listed Companies in Tehran Stock Exchange. Journal of Sutainable Develeopment.

Tanjung, H., \& Devi, A. (2013). Metode Penelitian Ekonomi Islam. Jakarta: Gramata Publishing.

Zamil, Nor Aiza Mohd., A. R. A. R. (2006). Efficiency of Sharia and Conventional Commercial Banks in Malaysia: A Data Envelopment Analysis (DEA) Study. 